Policy Research Working Paper 2126

\section{Liberté, Egalité, Fraternité}

Exploring the Role of Governance in Fertility Decline

Monica Das Gupta
Policies that foster local

accountability and social

mobility may be conducive

not only to rapid

development but also to

personal efficacy and rapid

fertifity decline.

The World Bank

Development Research Group

Regulation and Competition Policy

May 1999 
Policy Research Working Paper 2126

\section{Summary findings}

Within a short span of human history, a secular decline in fertility has taken place around the world. The timing and pace of this decline correspond broadly with changes in sociopolitical institutions in different parts of the world.

Das Gupta hypothesizes that this shift in childbearing behavior is related to cognitive changes wrought by the move from deeply hierarchical sociopolitical institutions to more egalitarian institutions of modern governance.

These changes have enabled socioeconomic mobility and improved people's ability to shape their own lives, internalizing more of the positive and negative implications of their decisions, including those about childbearing.

Recent work in development economics argues that policies that foster local accountability are the most conducive to rapid development. Das Gupta argues that they also foster personal efficacy and rapid fertility decline.

If true, her hypotheses indicate that one can expect development and fertility decline to be associated. Some policy environments may lead to "win-win" situations of rapid development and fertility decline, while others may generate "lose-lose" outcomes.

This paper - a product of Regulation and Competition Policy, Development Research Group - is part of a larger effort in the group to study social institutions and development outcomes. Copies of the paper are available free from the World Bank, 1818 H Street NW, Washington, DC 20433. Please contact Monica Das Gupta, room MC3-579, telephone 202-4731983, fax 202-522-1153, Interner address mdasgupta@worldbank.org. Policy Research Working Papers are also posted on the Web at http://www.worldbank.org/html/dec/Publications/Workpapers/home.html. May 1999. (24 pages)

The Policy Research Working Paper Series disseminates the findings of work in progress to encourage the exchange of ideas about development issues. An objective of the series is to get the findings out quickly, even if the presentations are less than fully polished. The papers carry the names of the authors and should be cited accordingly. The findings, interpretations, and conciusions expressed in this paper are entirely those of the authors. They do not necessarily represent the view of the World Bank, its Executive Directors, or the countries they represent. 


\title{
LIBERTE, EGALITE, FRATERNITE: exploring the role of governance in fertility decline
}

\author{
Monica Das Gupta \\ Development Economics Research Group \\ World Bank, 1818 H Street, N.W. \\ Washington, DC 20433 USA \\ Email:mdasgupta@worldbank.org
}

Revised version of Working Paper 97.06, Harvard University Center for Population and Development Studies. Comments from Abhijit Banerjee, Nirmala Banerjee, Andre Beteille, Shelah Bloom, Sissela Bok, David Bell, Mrinal Datta Chaudhuri, Gene Hammel, Sarwar Lateef, Mick Moore, Fabienne Peter, Debraj Ray, Pieter Streefland and George Zeidenstein on earlier versions of this paper are gratefully acknowledged. 


\section{LIBERTE, EGALITE, FRATERNITE: exploring the role of governance in fertility decline}

\section{Monica Das Gupta}

Reproductive behaviour has changed across the globe within the space of a century. Within this short span of human history, people around the world have shifted from having large to small numbers of children. This transition has taken place under very different local conditions: economic, political, social, cultural, and demographic. An enormous amount of work has gone into understanding reproductive change, and current theories range from those emphasising the role of specific changes such as family planning programmes, female education and improved child survival, to those stressing the role of broader ideational changes ${ }^{1}$. While all these explanations are important, they leave us with an uncomfortable diversity of explanations for the same fundamental shift in human behaviour. For both theoretical and policy purposes, it is useful to work towards an underlying theory to explain this phenomenon, one with some predictive power. This is especially important for the large parts of the world in which the transition is taking place slowly or is yet to begin.

We offer here some hypotheses which may contribute to a more general theory of fertility transition, with some predictive power as to what policies may affect the timing and speed of the transition. Our hypotheses derive from the observation that the timing and pace of the fertility transition correspond broadly with changes in socio-political institutions: whether we look at regions of the world, regions of one continent such as Asia or regions of one country such as India. This suggests that changes in reproductive behaviour form part of a much broader set of normative and cognitive changes sweeping the globe, following from changes in socio-political institutions.

To summarise our hypotheses, we argue that critical changes in reproductive motivations are wrought by the changes in socio-political institutions and forms of governance which have gradually spread across the world over the past two centuries. The first component of these changes is the breakdown of socio-political institutions based on deeply hierarchical social structures, which circumscribe the scope for people to be socio-economically mobile and to benefit (or lose) from the consequences of their own decisions. Secondly, the establishment of modern governance helps this process through the provision of law and order and other public goods which facilitate the use of opportunities for mobility. Thirdly, some forms of governance encourage participatory processes of local decision-making, which further enhances the potential for people to be socio-economically mobile and to develop a sense of personal efficacy. These changes profoundly influence people's ability and motivation to shape their own lives, including their reproductive lives.

Drawing on recent literature on the effects of institutional settings on the pace of economic development ${ }^{2}$, we suggest that the debate about the role of development in fertility decline may be misspecified insofar as it hinges on whether various forms of development preceded fertility decline. It may well be that both socio-economic development and fertility transition are driven by the same gamut of institutional changes. Thus, instead of expecting development consistently to precede fertility decline, we should perhaps view the two sets of changes as associated but not necessarily sequential in nature. 
Part of the reason for the present multiplicity of explanations for fertility decline lies in the fact that the factors singled out are often highly embedded in the local circumstances of the setting studied, and therefore focus on local-specific policies or forms of development. This leads to explanations which are not always applicable to other settings. For example, while it is clear that family planning programmes have played a very important role in accelerating the pace of fertility decline in many developing countries, other countries have experienced decline without such programmes (Martine 1996). Similarly, while fertility decline is clearly accelerated by factors such as the spread of education, health care and women's labour force participation outside the home, in many settings indices of these factors have been at low levels when fertility decline began. The multiplicity of current theories is also partly generated by differences in analytical methodologies, which can even result in very different explanations for fertility change in the same location (Das Gupta 1996). This makes it important to look beyond the blinkers placed by specific settings and methodologies in understanding the fertility transition.

Some major theories have looked to more global changes to explain fertility decline. For example, Notestein's (1953) well-known demographic transition theory spelt out a list of developments accompanying industrialisation and urbanisation in Europe which changed the incentives for childbearing. This theory was challenged by the results of the Princeton group's work on European historical demography, which failed to find any consistent thresholds in key development indicators which preceded fertility decline (Coale and Watkins 1986). Their work indicated that the timing of reproductive change differed between linguistic groups, giving rise to the suggestion that it is influenced by communication of ideas and ideational change. In this vein, the 'wealth flows' theory emphasises the role of Westernization in fertility decline (Caldwell 1976, 1978, 1980). More recent work has focussed on the diffusion of a small family norm and information on means of fertility control (Cleland and Wilson 1987, Pollak and Watkins 1993, Bongaarts and Watkins 1996). Others have argued that the Princeton study was too quick to reject the socio-economic model of fertility decline (Galloway et al.1994). Here we address this debate by trying to understand some of the reasons underlying the widespread behavioural shift, why people choose to have smaller families.

Our hypotheses build on McNicoll and Cain's (1989) theory of the role of institutional structures and local goverrment in creating the conditions for fertility decline. They are also related to the theory that fertility decline is influenced by ideational change and the diffusion of ideas. However, we focus not on the diffusion of small family norms and contraceptive information, but on the diffusion of ideas at the level of socio-political change. The world has undergone radical changes in socio-political systems during this period, and we argue that this may be related to changes in reproductive behaviour. Our hypotheses are also clearly related to ideas of the relationship betweenfertility and 'modernisation' or 'Westernisation', but they differ from these in their elucidation of the processes underlying the connection between institutional and cognitive change.

We begin by summarising the explanations given for fertility transition in different parts of India. This illustrates how, as the geographical and historical scope of analysis is widened, it becomes possible to move beyond the immediate local-specific factors into a broader understanding of the factors which speed or hinder fertility decline. We discuss how colonial administrative policies helped shape current regional differences in socio-political institutions and cultures of governance, 
which in turn influence the wide regional differentials in the pace of socio-economic demographic change. In the second section, we discuss our hypotheses, summarised above, about the factors underlying the global change in reproductive behaviour.

\section{EXPLANATIONS OF FERTILITY DECLINE IN INDIA}

\section{Reasons given for fertility decline in various parts of India}

Studies of India present a wide diversity of explanations for fertility decline. Perhaps because it is such a heterogenous country, in-depth studies of fertility in India tend to focus on a particular part of the country rather than the country as a whole. Here we review the explanations put forward for Kerala, Tamil Nadu, Punjab and Maharashtra, and for the slowness of the decline in the central states of the country. These explanations seem at first sight to be quite different from each other, but we shall argue that the underlying causes are similar across the country.

One of the striking features of fertility decline in India is the wide regional differences in the timing and pace of the transition. By 1991, Kerala and Tamil Nadu in south India approached replacement fertility levels and the majority of states had moderate fertility levels of around 3 children per woman, while the central states continued to have high fertility levels of around $4.5-5$ children per woman. Compared with the rest of the country, fertility transition in the central states not only began later, but also is proceeding more slowly (Table 1).

Kerala's fertility and mortality rates approach those of developed countries, an achievement which is especially remarkable in view of the state's lack of prosperity in comparison with the rest of India, let alone developed countries. Kerala is therefore often held up as a model of what can be accomplished in low-income settings given a political commitment to human development, in particular to providing universal education and health care. Efforts in this direction began as early as the nineteenth century, when the ruler of the princely state of Travancore-Cochin proclaimed that universal education and health care were desirable goals and began to set up schools and encourage missionaries to do the same. By the late nineteenth century quite substantial proportions of the population were educated, mostly amongst the higher castes. In the early decades of the twentieth century, education was spread actively to the lower castes (Krishnan 1995, 1996). The spread of health care also seems to have had some success (Krishnan 1995).

Social movements played an important role in this transition. Movements for religious reform in the late nineteenth and early twentieth centuries gradually broke down the rigidities of the caste system and loosened up traditional hierarchies. The lower castes in Kerala were active in measures such as establishing universal rights of access to temples, and using educational facilities to establishupward social and economic mobility. Kerala has also had several socialist movements, such as those to keep wage levels high and to protect workers' welfare. The population is almost universally literate and high proportions read newspapers on a regular basis and use the public libraries available to both urban and rural areas. As a result, people are highly politicised and are able to organise political pressure to ensure that public services such as health facilities are well run. These achievements are especially impressive in view of the fact that traditional social organisation in Kerala was amongst the most deeply inegalitarian in India. 
While Kerala presents an impressive example of the 'human development' path of demographic transition, Punjab represents the path of economic development with relatively little attention paid to social development until the late 1960s. Yet fertility began to decline in Punjab in the 1940s (Figure 1), around the same time as in Kerala ${ }^{3}$, though at a considerably slower pace. The decline began in Punjab almost a quarter of a century before the spread of education and the extension of the health and family planning programme. At that time infant mortality was over 150 per thousand, levels of literacy were negligible, and there was virtually no access to modern contraception. Moreover, though agricultural yields were rising steadily, levels of living in Punjab in the 1940s remained relatively low as compared with the affluence generated by the recent Green Revolution.

This fertility decline seems to have been triggered by colonial efforts to promote economic development in Punjab. In particular an ambitious effort to construct canals and wells to bring irrigation to this arid land was very successful in raising agricultural productivity. More importantly, assured irrigation stabilised yields, making for a new security of life and livelihood for all strata of the population, and increasing stability of expectations (Das Gupta 1995). These were critical factors enabling people to reduce fertility in response to the pressure on resources caused by mortality decline. Fertility was reduced using traditional methods including postponing marriage and terminal abstinence, and the advent of modern contraception since the 1960s facilitated this considerably.

Tamil Nadu has the second lowest fertility rate in India and is also approaching replacement fertility. There is less consensus about the reasons for fertility decline in Tamil Nadu than in Kerala. This state has gone down the path of social development mixed with economic development (Kishor 1994, Ramasundaram 1995). Levels of education and mortality are not as favourable as in Kerala, but compare favourably with the rest of India. Tamil Nadu underwent steady industrial growth during the 1950s and 1960s, and became one of the more industrialised and urbanised states of the country (Kishor 1994, Ramasundaram 1995). During this period, public irrigation facilities were expanded, raising agricultural productivity and laying the basis for a further rapid rise in production when the inputs of the Green Revolution became available. Despite these efforts, Tamil Nadu ranks below average amongst Indian states in per capita income.

Turning to social development initiatives, levels of literacy, including female literacy, have risen rapidly in Tamil Nadu during recent decades, and as Kishor (1994) points out, the emphasis has been on spreading elementary education. Other equity-oriented efforts abound in the state. Land reform, tenancy legislation and wage legislation were passed, aimed at protecting the poor (Kishor 1994, Ramasundaram 1995). Health service provision has been greatly expanded, and innovative nutritional supplement programmes carried out. Since 1982, there has been a free lunch programmefor children aged 2-10 years registered in child welfare centres and elementary schools, which is found to have improved diets and reduced poverty (Kishor 1994). Tamil Nadu also has a record of aggressive affirmative action efforts to raise the status of the lower social classes (Ramasundaram 1995, Bhat 1997).

Some have argued that Tamil Nadu's fertility decline is 'poverty-driven'4. This argument seems to hinge not on an absolute reduction of living standards, but on aspirations rising faster than household resources. Kishor, for example argues that the poor have been left with no choice but to 
shift over to investing in their children's education to enter the urban job market. Rising aspirations give further impetus to the need to reduce family size. This argument, of course, is premised on the availability of jobs in the urban areas, which itself is indicative of economic growth and the spread of economic opportunities.

Mari Bhat (1996) finds no evidence that Tamil Nadu's fertility decline is 'poverty-led'. His analysis points out that the electronic media are especially widespread in Tamil Nadu, and that in this state media exposure has an especially strong inverse relationship with fertility. Another argument sometimes put forward is that the decline is due to an especially active and innovative family planning programme, but this argument has also been dismissed in recent analyses (Ramasundaram 1995, Bhat 1997). It seems that Tamil Nadu's fertility decline is driven by a combination of social development policies and new opportunities for mobility and raising aspirations.

In his comparison of Maharashtra and Bangladesh in the late 1970s, Cain (1981) emphasised the contrast between the institutional structures in the two settings. In particular, he drew attention to Maharashtra's efforts to generate employment and provide credit, and the relatively smooth operation of the legal system in protecting property rights. He attributed the more advanced fertility transition in Maharashtra as compared with Bangladesh to the security brought about by these aspects of administrative order, along with the relatively greater autonomy of women.

Many of the apparent contradictions between the explanations of fertility decline in various parts of India are resolved when these are contrasted with the central states of the country. These states show the slowest fertility decline and are the most disadvantaged in economic as well as social development. They have the lowest per capita income levels in the country and show poor performance on agricultural as well as industrial development indicators. Eastern Uttar Pradesh and Bihar are the worst outliers on these fronts. Maternal and child mortality rates remain high, illiteracy is high and the family planning programme is viewed as performing poorly. Satia and Jejeebhoy (1991) conclude that these various aspects of underperformance reinforce each other.

This suggests that whether states have placed greater emphasis on economic development or on social development is of far less consequence than whether they have placed emphasis on development at all. Both forms of development have in common the feature that they make for greater security of life and aspiration to improved living conditions, thus motivating and enabling people to plan under conditions of far less uncertainty about the future ${ }^{5}$. The shift is from a mindset in which people respond to circumstances as they arise, to one in which they feel they can reasonably direct the course of their lives, including the number of children they would like to raise. Both forms of development, then, can bring about the onset of fertility decline. However, thecomparison of Kerala and Punjab indicates that the pace of the decline is more rapid where social development proceeds more rapidly.

\section{The influence of administrative policies in colonial India (presentday India, Bangladesh and Pakistan)}

The roots of some of the variation in the timing of demographic transition in different regions of India can be traced to administrative policies during the colonial period. The nature of the colonial 
administration differed across India, and deeply influenced the nature of local economic, social and political institutions. Perhaps the most important way in which the colonial administration differed across India, from this point of view, was the method of collecting revenue. The land settlement laid out the basic framework for revenue collection.

In some parts of the country, such as the eastern and central region including Bengal, Bihar and Eastern Uttar Pradesh, the arrangement was to have large landowners (zamindars, talukdars) who were responsible for payment of the revenue. This system was deeply hierarchical, with the landowners being far removed from actual cultivation and living off rent collected from tenant farmers. The landowners formed part of the local elite, and had a virtual monopoly of power in local institutions.

These hierarchical power structures persist to a substantial extent even today in Bihar and Eastern Uttar Pradesh, where economic and political power are still highly concentrated and the elite have considerable success in slowing down the pace of state efforts to transform the local economy and society. These are the parts of India which are most poorly administered, largely because of the pressures from local elites. state interventions to bring education, health and agricultural and other development have met with limited success in these areas as compared with the rest of the country, because the elites have strong vested interests in maintaining the old hierarchies.

In West Bengal, political pressures made for the abandonment of these structures after Independence. Much has been done since then to sweep away their residual effects through the spread of education, organisation of active participation by people in local political processes, land reform, agricultural development and other forms of development. West Bengal has experienced substantial fertility decline. In East Bengal (presentday Bangladesh) these tenurial systems began to break down after Partition, as the large landowners were mostly Hindus who left at the time of Partition.

After Bangladesh became independent, more concerted administrative efforts, both public and private, have come into place. This is evident in the recent growth rates of the economy and in the reduction of mortality rates from the natural disasters which beset the country (Das Gupta and Narayana 1996). When researchers such as Cain (1977) first went to study Bangladesh, this was shortly after Independence and in the wake of a major famine, so they were struck by the harsh environment of risk which gives incentives for high fertility. Since then much has been done to reduce the environment of risk with water management, disaster relief and other strategies, and to diversify sources of income for people (Hossain 1992, Cleland et al. 1994). Much of Bangladesh's development effort has been highly participatory (Bardhan 1996, Crook and Manor 1994), and thismay help explain the striking fertility decline that has recently taken place there. The translation of a. latent demand into actuality has been greatly facilitated by improved access to modern contraception.

In other parts of present-day India, including Punjab and Haryana and much of the south, there was a more egalitarian form of land settlement, in which revenue was collected directly from peasant owner-cultivators. In these areas there was far less concentration of landholding and economic and social power, and the beneficial effects of this are visible even today in the greater effectiveness of 
state interventions and the dynamism of a local economy in which people have an incentive to invest in increasing production. Whether one looks at the spread of education, the functioning of health centres, or agricultural growth, these more egalitarian economic structures show far greater success than the central region of the country where deeply unequal structures still linger.

There was also considerable variation in the extent to which the colonial administration actively tried to develop the local economy. The Province of Punjab (including presentday Indian Punjab, Haryana and Pakistan's Punjab Province) had an especially committed administration in this regard. This may have been motivated partly by the fact that this was the part of the country from which it was felt that the most loyal troops could be recruited for the army. Also, Punjab had vast arid tracts which, with investment in irrigation, could be turned into a very fertile region. The construction of an ambitious system of canals and the spread of irrigation was rewarded by this region becoming a major source of grain exports and revenue generation.

While the whole of Punjab benefited greatly from the developmental efforts of the colonial government, there were important differences within the region. The western part of Punjab (now in Pakistan) was arid and thinly populated, while population density was higher in areas further east (now in India). It was the western part which was opened up by the canals into what were called the Canal Colonies. Here large tracts of newly canal-irrigated land were granted to settlers brought in from eastern Punjab, and these became the breadbasket of colonial India and the source of massive wheat exports to other countries (Darling 1947). The other parts of Punjab (now mostly in India) were already settled, and were largely dominated by peasant owner-cultivators. The middle part of the region (now Indian Punjab) also benefited from some of the canal irrigation, but also from well irrigation. The easternmost part (now Indian Haryana) was the most densely populated, with small landholdings and the least development of canal irrigation. It was the part of Punjab most subject to famine during the colonial period, and continues today to be less prosperous than Indian Punjab.

Thus the parts of Punjab province which fall in presentday Pakistan came to be dominated by large powerful landowners, whereas those which fall in presentday India were largely the domain of peasant owner-cultivators with more egalitarian social structures. This may help to explain why the fertility transition has occurred much more rapidly in Indian Punjab than in Pakistani Punjab, although fertility levels were similar before Independence (Dyson 1996). There is also a historical difference between Indian Punjab and Haryana, with the latter being subject to insecurity for longer than the former. This may help to explain why Haryana's fertility decline has lagged somewhat behind that of Indian Punjab.

\section{Towards a synthesis of explanations for fertility decline in India}

The Indian experience suggests that growing pressure of population on resources generated a latent demand for reducing family size, but that improved security of life and new aspirations for mobility were important for enabling people to respond to their perceived pressure on resources. The most rapid fertility decline has been in those parts of the country characterised by more egalitarian economic and political institutions, and better governance as reflected in development outcomes and a stable legal order. These are also the parts of the country with the most participatory processes of development. During the pre-Independence era, this was especially true of Punjab and 
Travancore-Cochin (parts of present-day Kerala), although they laid different emphases on social versus economic goals.

In the central states, power remained more concentrated and the scope for mobility low, and reproductive behaviour has been slower to change. These states are characterised by considerably poorer governance than the rest of the country. This is reflected in virtually any indicator one chooses to examine: including low levels of education, high child mortality rates, slow fertility decline, poor utilisation of water tables for irrigation, low agricultural wages, and low levels of industrialisation. The environment of risk in daily life remains far higher in these states than elsewhere, whether in earning a livelihood or one's children's survival chances. These are the only parts of the country where dacoits continue to flourish, frequently supported by or even drawn from local elites, where female health workers have to be careful of their movements, and where local landlords continue to use physical force to keep wages low. All this is despite the fact that the basic sectors of health and education and legal and administrative institutions are designed to be uniform throughout the country.

As we argue above, historical factors have helped shape regional differences in patterns of governance, and these in turn have influenced the pace of socio-economic and demographic change. There is considerable overlap between the states with slower fertility transition and poorer child health, poorer reproductive health services, lower literacy, less industrialization and less administrative efficiency (as measured by the coverage of the vital registration system) (Table 1). People are less enabled to control fertility not only because they have less access to education, health and family planning services, but also because their lives are far less secure and amenable to improvement through personal efforts than elsewhere in the country. Fortunately there are many pressures operating against the continued dominance of local elites in these regions, so positive changes are taking place, albeit painfully slowly.

\section{INSIGHTS FROM A GLOBAL PERSPECTIVE}

The timing of fertility decline in different parts of the world sheds light on what policies helped alter people's reproductive behaviour. Figure 2 shows that the timings of country-specific declines are clustered by region. Thus Western European countries experienced their transition around the late nineteenth to early twentieth century: some countries were earlier and some were later, but (with the exception of France) they all fall within a broad band of decline around the same time. Next came countries in Latin America and Asia, whose fertility decline began in the mid-twentieth century, and some of these have now reached quite low levels of fertility while others continue to have moderate fertility. Sub-Saharan Africa is not shown here, as decline has begun only recently insome countries and not yet in others.

This raises the question of what might have caused this regional clustering. The timing of fertility decline coincides broadly with that of the development of modern states with modern administrative institutions, suggesting that these may have influenced reproductive behaviour. France was the first to experience the ideological upsurge that led to the demise of its monarchy, as well as the earliest onset of a secular decline in fertility. Most of the rest of Western Europe experienced this socio-political shift over half a century later, that is around the mid to late 
nineteenth century, and experienced fertility decline from around the late nineteenth century (Knodel and van de Walle 1986). Most of the rest of the world underwent these socio-political changes around the mid-twentieth century, and fertility decline also started very roughly after that.

Within Asia also, regional differences in the timing and pace of fertility decline (Figure 3) indicate that they may be influenced by the nature of governance, as discussed above in the context of India. Around 1950, most Asian countries had a total fertility of around 6, but their subsequent paces of fertility decline were very different, generating a wide range in fertility levels by 1995 . Some Asian countries now have some of the lowest fertility rates in the world, while others have some of the highest. Differences within South Asia are just as wide, with Sri Lanka at 2.3 and Pakistan at 5.26. The same is true within India, where total fertility in 1991 ranged from 1.8 in Kerala to 5.2 in Uttar Pradesh $^{7}$ : within a single country, levels of fertility are amongst the lowest in the world in some regions and amongst the highest in others.

These differences within Asia seem to correspond with differences in socio-political institutions, as indicated by the nature of land tenure and agrarian relations; differences in the operation of the state as indicated by law and order; and differences in the extent to which local decision-making takes place through participatory processes. We describe below how these factors may influence reproductive behaviour.

\section{Shift away from hierarchical socio-political order:}

During the nineteenth and twentieth centuries, most of the world underwent profound transformation in relations of political economy, accompanied by changes in the nature of administration. Earlier relations of political economy, based on deeply hierarchical social structures, were gradually replaced by those associated with modern states 8 . These earlier socio-political structures were based on a concentration of social, economic and political power in the hands of local elites, who were typically responsible for collecting revenue and administering local justice. They operated on multistranded ties of patronage with the local peasants. States gradually undermined the power of these elites and dealt with the populace directly. Some historians argue that this was motivated by a need to tax citizens directly in order to finance modern warfare (Weiss and Hobson 1995). In the process, they established direct administrative ties with their citizens. Hobsbawm (1990:83) calls this process 'the creation of the modern, administrative, citizenmobilizing and citizen-influencing state'.

The modern state tends towards an egalitarian orientation because in order to acquire legitimacy, it must invest in some aspects of their citizens' welfare. It needs to foster citizens' compliance in its military and economic endeavours, and to ensure citizens fitness for these purposes (Hobsbawm1990, de Swaan 1988). This motivates states to invest in the health and education of the populace. In most West European countries, much emphasis has been given since the late nineteenth century to matters such as improving citizen's housing, nutrition, education, health education, public health, and sanitation. In much of the developing world, these processes began several decades later.

These changes destroy pre-existing relations of political economy and fundamentally alter people's lives. In the hierarchical relations of political economy, ties of obligations between overlords and their underlings often provided the latter some measure of insurance while severely circumscribing 
individual mobility. The combination of patronage and exploitation ${ }^{9}$ which this entails means that people do not live with the implications of their own choices and actions, for better or for worse. The personalised sources of insurance are highly elastic, offering greater support when times are very bad and less when they are better. For the patron, this ensures their clients' continued survival and availability for work. For the clients, it blurs perception of the costs and benefits of alternate courses of action. Constraints on mobility and aspirations add to people's sense of limited ability to improve their lives through their own actions. When these ties end, some important constraints on mobility are lifted, along with the generalised insurance: creating both the possibility and the incentive to try to improve one's own situation ${ }^{10}$.

From the point of view of altering reproductive behaviour, both the positive and the negative aspects of these changes are significant. They have profound effects on raising personal efficacy, enabling people to shape their own future, while also forcing them to absorb to a greater degree the consequences of their own actions. While obligations remain elastic, people under-internalise the costs of child-bearing. This has been pointed out in the case of family systems which allow the costs of childbearing to be spread beyond the parents (Davis 1955, McNicoll and Cain 1989), and we extend this idea to the sphere of socio-economic structures. The possibility of mobility adds further to people's need to consider their reproduction carefully.

Other changes during this period work in the same direction of less elastic obligations and increased mobility. For example, the shift from an agrarian to an industrial economy dramatically reduces the scope for disguised unemployment. It also entails a shift from working relations based on sustained social ties to contractual relations. At the same time, other sources of elastic obligations may continue to exist, for example within the kinship group or community (such as common property resources). A different kind of elasticity can also prevail if, for example, new land can be opened up relatively easily for cultivation.

\section{Establishment of modern governance:}

This fundamental transformation in socio-political structures is linked with the establishment of modern governance. As mentioned above, the activities of a modern state influence the daily life of ordinary people in ways unthinkable in earlier times. A central feature of this is the establishment of law and order and of policing as a public good. This can exist even where the rule of law is very weak, as for example in totalitarian and many authoritarian regimes: conversely, Bihar in India is a good example of a place which has rule of law but very poor law and order. When security becomes a public good as opposed to a private good, people become less dependent on social ties for protecting such things as property. Also important for increased security are measures improving public health and stabilising food availability. These reduce the sudden mortality peaks whichconstitute such a capricious threat to people's lives. Thus in many ways people in most settings have more security of life and livelihood today, despite losing erstwhile sources of generalised insurance.

Other institutional innovations brought about by the public or private sector make for greater economic growth and security. These include the creation of modern infrastructure for credit, transport, marketing and communications. The spread of education also increases people's ability to shape their lives. Informal insurance mechanisms, embedded in personalised ties with elastic obligations, are gradually substituted by more impersonal institutions. This also increases the 
potential for socio-economic mobility, and with this the need to plan family size more precisely. An unusually detailed study of Prussia during 1875-1910 brings out the importance of these kinds of institutional innovation for fertility decline (Galloway et al.1994).

The specifics of the change vary considerably, as the manifestations of modern governance may take very different paths. One obvious difference is that modern administrations may have different policy objectives. As the Indian case shows, in some settings policies may focus on social development, while elsewhere they emphasise economic growth. These different paths have quite different ramifications apart from the obvious differences in the quality of life. For example, social development is more likely to foster gender equality and social equality than economic development. As suggested by the more rapid fertility decline in Kerala than Punjab state of India, social development may also be associated with more rapid growth of personal efficacy, and consequently more rapid demographic transition. Thus the specifics of the forms of modern governance can differ considerably and affect the pace of demographic transition.

\section{Participatory processes of local governance:}

One important aspect of governance which we hypothesise influences the fertility transition is the organisation of local government. Recent work $^{11}$ on the role of institutions in economic development stresses that systems of governance which foster participatory processes in local decision-making and local accountability are more successful in achieving development goals. Some forms of bureaucratic organisation are better at generating the synergy between the public and private sectors which increase people's ability to influence developmental outcomes and accelerate growth (Evans 1995, 1996). There is good reason for expecting that such settings will be characterised by better outcomes in several spheres, ranging from health and education to irrigation and credit. Putnam (1993) found this to be the case in Italy. He even found that infant mortality rates in different regions of Italy in the 1970s were predicted far better by initial differences (at the turn of the century) in social capital than by initial differences in infant mortality rates at that time.

Note that democracy at the national level and participatory development with local accountability do not necessarily go hand in hand (Bardhan 1996; Isham et al.1995), although democratic regimes lend themselves more obviously to the checks and balances required for the maintenance of civil society and modern governance. Several authoritarian regimes have been oriented towards economic and social development, and have proved effective in establishing modern governance. At the same time, some democratic regimes have been poor at creating participatory institutions of governance, particularly at local levels.

For example, Wade $(1982,1985,1997)$ concludes that participatory development at the local level was far better ensured under South Korea's military dictatorship than under India's elected government. This is reflected in the greater effectiveness of the organisation of the South Korean irrigation system, which make for greater responsiveness of local irrigation officials to farmers' needs than in India. Evans (1995) comes to similar conclusions in comparing industrial development outcomes in South Korea and India. In the same vein, Dreze and Saran (1993) conclude that China's better performance than India in primary education is attributable largely to better institutions of local accountability in such matters in China. 
We extend this idea to argue that more participatory local governance is also conducive to more rapid fertility decline. This is partly because more rapid development enlarges the scope for socioeconomic mobility, and partly because greater participation in local government sharpens people's perception of the connection between their own actions and their well-being. This hypothesis is consistent with the evidence from Asia, where regional differences in the extent of participation in local decision-making seem to correspond with differences in the pace of both socio-economic development and demographic transition.

For example, East Asian countries such as South Korea and China were ravaged by war in the midtwentieth century, but ironically this facilitated land reform and some critical decentralisation of local decision-making which have helped them greatly in their subsequent development. By contrast, India has experienced much more political and administrative stability, with the negative consequence that some areas remain quite feudal in nature and others have shown inadequate success in fostering local accountability. We hypothesise that this helps explain why fertility transition has been more rapid in East Asia than in South Asia, as well as the striking regional differences in fertility transition within South Asia (Figure 3).

\section{The role of technological change in accelerating the pace of fertility decline:}

Developmental efforts were given an enormous boost from the late nineteenth century onwards by scientific advances on many fronts. Improved engineering techniques and materials made it possible to build infrastructure such as railroads, dams and canals on a scale never imaginable earlier. This reduced people's susceptibility to risk in a variety of ways, such as by reducing dependence on rainfall and making it possible to transport food to avert famine. Radically new medical discoveries enabled effective intervention to improve public health and dramatically reduce the risk of sudden death which had till then always beset humanity.

Accompanying these scientific advances was a great surge of confidence in man's ability to master nature. This was a radical departure from previous ideologies which were necessarily based on a more resigned acceptance of the vagaries of nature. It is a truly heady idea, that mankind can control its own destiny, and that many human problems can be resolved through technological means. Colonial administrators commented on the psychological sea-change brought about by the advent of canal irrigation in northern India:

The whole framework and order of society are changed, and men are no longer entirely at the mercy of nature and of fate....The man-made canal is beginning to take the place of fate in men's minds, and it is only a step from this to realize that if man can make the canal, hecan make much else besides; and that it is not 'as God wills' but as man works that he will be rich or poor....The change is one the subtlest influences now coming into play, and as it spreads, will do more than anything else to make agricultural progress possible. (Darling 1947:146-147, originally published in 1925)

Thus a dramatic set of scientific advances altered not only people's ability but also their perception of their ability to shape their own lives, including their reproductive lives. 
More recent scientific advances have also had enormous impact on the pace of fertility decline. An obvious example is the advances in contraceptive technology, which has dramatically reduced the effort involved in preventing births. The mass media offer a very direct example of how new technology can accelerate fertility decline. By bringing radically new information and messages into people's homes, the media are able to act in many subtle ways to accelerate the pace of change of group norms. For example, in the absence of media, group norms can be expected to change gradually, as some individuals in a community realise the potential benefits of reducing fertility. As their children grow and the family is apparently successful in their new strategy, others will follow their example. With the advent of the media, this entire process can be speeded up. For example, a soap opera can introduce demographic innovators simultaneously in every community, and within $\vec{a}$ few weeks show that their children grew up successfully. Thus the media simultaneously introduce demographic innovators and their instant success, which accelerates the pace of change of group reproductive norms. New contraceptive and media technology have helped make the pace of fertility decline more rapid in countries starting their decline in the mid-twentieth century than in those that began before this.

\section{CONCLUSIONS}

The nature of our understanding of the factors underlying fertility decline is deeply affected by the analytical methodologies used, and by the historical and geographical scope of the analysis, as we illustrate here. Apparently very different theories emerge from studies carried out in different parts of India: we are told that the key factor in Kerala was social development, while in Punjab it was economic development, in Maharashtra modern institutional structures and in Tamil Nadu some combination of these.

Yet these diverse explanations have an underlying commonality, namely that in India fertility transition has taken place where established socio-economic and political hierarchies have been shaken up, increasing the scope for individual mobility, security and control over life. Conversely, the slowest development and demographic transition are seen in regions which are still controlled by powerful landowners. It is of course in the interest of these landowning elites to maintain their power by subverting processes which would increase people's security and personal efficacy. Perhaps this is also one reason why Pakistan has experienced such slow fertility decline.

Moving to the still larger canvas of global fertility decline, we observe that the timing of fertility decline in different regions of the world corresponds broadly with changes in socio-political institutions. We hypothesise that fertility decline is related to these changes, which have led in various ways to lifting constraints on mobility and enabling people to shape their own lives, internalising more of the positive and negative implications of their decisions, including their reproductive decisions. This has also been powerfully helped by the success of modern science in giving mankind a sense of control over its own destiny.

One change which is crucial in this respect is the breakdown of deeply hierarchical socio-political institutions, which brings the possibility of equality of opportunity and of socio-economic mobility. Another important change is the establishment of modern governance, a central feature of which is 
the establishment of law and order and of policing as a public good. This can exist even where the rule of law is very weak, as in most authoritarian states, while conversely Bihar state of India illustrates that it is possible to have very poor law and order despite having rule of law. Modern governance brings security and predictability of life and livelihood through impersonal institutions, which is crucial for people to plan their lives.

Polities which are successful in fostering local accountability and participation in decision making show the most successful development outcomes of several kinds, ranging from health and education to irrigation and credit. This does not necessarily go hand in hand with democracy at the national level, as recent studies comparing India with South Korea and China emphasise ${ }^{12}$. We observe that such polities also seem to show the most rapid demographic transition. This is perhaps partly because they increase people's sense of personal efficacy and partly because they increase the pace of development and thereby the scope for benefiting from changing reproductive behaviour. We hypothesise that this helps explain the striking differentials in the pace of fertility transition between different regions of India, and between the countries of East and South Asia.

Drawing on the recent literature on the relationship between institutional settings and the pace of economic development ${ }^{13}$, we suggest that several aspects of socio-economic development (including fertility transition) may be driven by the same underlying forces of institutional change. If true, this has an important implication for our understanding of the relationship between development and fertility decline: namely, that while they can be expected to be associated with each other, they are not necessarily sequential in nature. Thus, for example, we should not be surprised to find fertility declining when levels of infant mortality are still relatively high or when standards of living are still quite low, as has empirically been the case in large parts of the world. Our hypotheses also suggest that entire communities are likely to experience changes in childbearing incentives at much the same time, and we should not necessarily expect large behavioural lags between different strata of a given community ${ }^{14}$.

The ideas put forward here are speculative. They represent a step towards understanding why a secular decline in fertility should have taken place across the globe within such a short span of human history, and why there seems to be a broad correspondence between the advent of political and institutional changes in different parts of the world and the timing and pace of fertility decline. If our hypotheses are valid, they indicate that policies to ensure more local accountability and decentralisation of development will effect a 'win-win' situation of more rapid development as well as more rapid demographic transition. Conversely, a paucity of such policies will result in the 'loselose' situation that parts of South Asia appear to face. 


\section{NOTES}

${ }^{1}$ See for example Bongaarts and Watkins (1996), Caldwell (1976, 1978, 1990), Cleland et al.(1994), Cleland and Wilson (1987), Cleland et al.(1994), Coale and Watkins (1986), Notestein (1953), Lesthaeghe (1983) and Pollak and Watkins (1993).

${ }^{2}$ See for example Evans (1995, 1996), Wade (1982, 1985, 1997), Putnam (1993), Isham et al.(1995) and Bardhan (1996).

${ }^{3}$ The age-distribution of Kerala indicates that fertility decline began in the 1940 s.

${ }^{4}$ Kishor (1994). See also Mencher (1980) and Basu (1986).

${ }^{5}$ This is akin to Coale's (1973) concept of fertility control entering people's 'calculus of conscious choice'.

${ }^{6}$ World Bank (1997).

${ }^{7}$ Registrar-General of India, Sample Registration System 1991.

${ }^{8}$ See for example Skocpol (1994), Weiss and Hobson (1995), Hobsbawm (1975, 1990), Moore (1978, 1993). Africa may be an exception to this argument because socio-economic relations there were far more egalitarian than in most of Europe or Asia. Arguably, many African societies have moved towards greater hierarchy during this century. In the case of Africa, a major source of elasticity is land availability: the phenomenon of land shortage and carefully defined property rights which have long been common in Europe and Asia is a recent feature in much of Africa.

${ }^{9}$ This wonderfully apt phrase is the title of Jan Breman's (1974) book.

${ }^{10}$ One example of this is the sharp rise in agricultural productivity that frequently takes place when land tenurial systems move towards owner-cultivation (Hobsbawm 1975, Banerjee and Ghatak 1996).

${ }^{11}$ See references in footnote 2 .

${ }^{12}$ See especially Bardhan (1996), Wade (1997), Dreze and Saran (1993), Isham et al.(1995) and Evans (1995).

${ }^{13}$ See references in footnote 2 .

${ }^{14}$ 'This is consistent with Cleland's (1993) observation that fertility decline sweeps through all socio-economic strata of a region with little of the lag which would be expected if indeed people were finetuning their decisions in response to their individual circumstances. 


\section{REFERENCES}

Acemoglu, Daron and James A.Robinson.1996. Why did the West extend the Franchise? Democracy, inequality and growth in historical perspective (manuscript).

Banerjee, Abhijit and Maitresh Ghatak.1996. Empowerment and efficiency: the economics of tenancy reform (manuscript).

Bardhan, Pranab.1996. Decentralised Development, Indian Economic Review XXXI(2):139-156.

Basu, Alaka Malwade. 1986. Birth control by assetless workers in Kerala: the possibility of a poverty-induced fertility transition, Development and Change 17(2): 265-282.

Bhat, P.N. Mari. 1997. Emerging Regional Differences in Fertility in India: Causes and Correlations in George Martine, Monica Das Gupta and Lincoln C. Chen (eds.) Reproductive Change in Brazil and India, New Delhi: Oxford University Press, in press.

Bongaarts, John and Susan C.Watkins. 1996. Social interactions and contemporary fertility transitions, Population and Development Review 22(4):639-682.

Breman, Jan. 1974. Patronage and Exploitation: Changing Agrarian Relations in South Gujarat, India. Berkeley, California: University of California Press.

Cain, Mead. 1977. The economic activities of children in a village in Bangladesh, Population and Development Review 3(3):201-227.

Cain, Mead. 1981. Risk and insurance: perspectives on fertility and agrarian change in India and Bangladesh, Population and Development Review 7(3):435-474.

Cain, Mead. 1983. Fertility as an adjustment to risk, Population and Development Review 9(4):688-702.

Caldwell, John C. 1976. Toward a restatement of demographic transition theory, Population and Development Review 2(3/4): 321-366.

Caldwell, John C. 1978. A theory of fertility: From high plateau to destabilization, Population andDevelopment Review 4(4):553-577.

Caldwell, John C. 1980. Mass education as a determinant of the timing of fertility decline, Population and Development Review 6(2):225-255.

Census of India 1901, Punjab, Part I: Report.

Census of India 1911, Punjab, Part I: Report, and Part II: Tables. 
Cleland, John C. and Chris Wilson. 1987. Demand theories of the fertility decline: an iconoclastic view, Population Studies 20: 149-174.

Cleland, John C. 1993. Equity, security and fertility: a reaction to Thomas, Population Studies 47(2):345-352.

Cleland, John G., J.F.Phillips, S.Amin and G.M.Kamal. 1994. The Determinants of Reproductive Change in Bangladesh, Washington D.C.: The World Bank.

Coale, Ansley J. 1973. The Demographic Transition Reconsidered, Proceedings of the International Population Conference, Liege, Vol.1: 53-72.

Coale, Ansley J. and Susan Cotts Watkins. 1986. The Decline of Fertility in Europe, Princeton, N.J.: Princeton University Press.

Crook, R. and J.Manor. 1994. Enhancing Participation and Institutional Performance: Democratic Decentralisation in South Asia and West Africa, Report to Overseas Development Administration, U.K.

Darling, Malcolm. 1947. The Punjab Peasant in Prosperity and Debt, Fourth Edition, London: Oxford University Press.

Das Gupta, Monica. 1994. What motivates fertility decline?: a case study from Punjab, India in B.Egero and M.Hammarskjold (eds.) Understanding Reproductive Change, Lund, Sweden: Lund University Press.

Das Gupta, Monica. 1995. Fertility decline in Punjab, India: parallels with historical Europe, Population Studies 49(3).

Das Gupta, Monica. 1996. Liberte, Egalite, Fraternite: the demise of "feudalism" and establishment of modern governance as causes of fertility decline, paper presented at the IUSSP seminar on Comparative Perspectives on the Fertility Transition in South Asia, Islamabad, 17-20 December 1996.

Das Gupta, Monica and D. Narayana. 1997. Bangladesh's fertility decline from a regional. perspective, Genus LIII(3-4): 101-128.

Das Gupta, Monica, George Martine and Lincoln C.Chen. 1998. Reproductive change in India and Brazil: implications for understanding fertility decline, in G.Martine, M.Das Gupta and L.C.Chen (eds.) Reproductive Change in India and Brazil, New Delhi: Oxford University Press.

Davis, Kingsley. 1955. Institutional patterns favouring high fertility in underdeveloped areas, Eugenics Quarterly 2:33-39. 
de Swaan, Abram. 1988. In Care of the state: health care, education and welfare in Europe and the USA in the modern era, Cambridge UK: Polity Press.

Dreze, Jean and M. Saran, 1993. Primary education and economic development in China and India: overview and two case studies, London School of Economics (manuscript).

Dyson, Tim. 1996. Birth Rate Trends in India, Sri Lanka, Bangladesh and Pakistan: à Long, Comparative View, paper prepared for the IUSSP seminar on Comparative Perspectives on the Fertility Transition in South Asia, Islamabad, 17-20 December 1996.

Dyson, Tim and Monica Das Gupta. 1997. Mortality Trends in Ludhiana District, Punjab, 1881-1981 in Ts'ui-jung Liu et al. (eds.) Population History of Asia, Oxford: Clarendon Press, in press.

Evans, Peter B. 1995. Embedded Autonomy: states and industrial transformation, Princeton, N.J.: Princeton University Press.

Evans, Peter B. 1996. Government action, social capital and development: reviewing the evidence on synergy, World Development 24(6): 1119-1132.

Galloway, Patrick.R, Eugene A.Hammel and Ronald D.Lee. 1994. Fertility decline in Prussia, 1875-1910: a pooled cross-section time-series analysis, Population Studies 48(1): 135-58.

Hobsbawm, Eric.1975. The Age of Revolution 1789-1848, London: Weidenfeld and Nicholson (first impression 1975).

Hobsbawm, Eric. 1990. Nations and Nationalism since 1780: Programme, Myth, Reality, Cambridge UK: Cambridge University Press.

Hossain, Mahabub. 1992. Structure and Distribution of Household Income and Income Dimensions of Poverty, in M.Hossain et al. Rethinking Rural Poverty: a case for Bangladesh, Dhaka: Bangladesh Institute of Development Studies.

International Institute for Population Science (IIPS). 1995. National Family Health Survey (MCH and Family Planning), India 1992-93. Bombay: IIPS.

Isham, J., D.Narayan, and Lant Pritchett. 1995. Does Participation Improve Performance? Establishing Causality with Subjective Data, World Bank Economic Review, May.

Kishor, Sunita. 1994. Fertility Decline in Tamil Nadu, India in B.Egero and M.Hammarskjold (eds.) Understanding Reproductive Change, Lund, Sweden: Lund University Press. 
Knodel, John and Etienne van de Walle. 1986. Lessons from the Past: Policy Implications of Historical Fertility Studies in Ansley Coale and Susan Cotts Watkins (eds). The Decline of Fertility in Europe, Princeton, N.J.: Princeton University Press.

Krishnan, T.N. 1995. The Route to Social Development in Kerala, Study prepared for the World Summit on Social Development, March 1995.

Krishnan, T.N. 1996. Social Development and Fertility Reduction in Kerala in George Martine, Monica Das Gupta and Lincoln C. Chen (eds.) Reproductive Change in Brazil and India, New Delhi: Oxford University Press, in press.

Lesthaeghe, Ron. 1983. A century of demographic and cultural change in Western Europe: an exploration of underlying dimensions, Population and Development Review 9(3): 411-435.

Mamdani, Mahmood. 1972. The Myth of Population Control, New York and London: Monthly Review Press.

Martine, George. 1996. Brazil's fertility decline, 1965-95: a fresh look at key factors, Population and Development Review 22(1): 47-75.

McNicoll, Geoffrey and Mead Cain. 1989. Institutional effects on rural economic and demographic change, in G.McNicoll and M.Cain (eds.) Rural Development and Population: institutions and policy, supplement to Population and Development Review 15:3-42.

Mencher, Joan P. 1980. The lessons and non-lessons of Kerala: agricultural labourers and poverty, Economic and Political Weekly 15(41/42/43).

Moore, Barrington. 1978. Injustice: the social bases of obedience and revolt, White Plains, N.Y.: M.E.Sharpe.

Moore, Barrington. 1993. Social Origins of Dictatorship and Democracy: lord and peasant in the making of the modern world, Boston: Beacon Press.

Nag, Moni. 1983. The impact of social and economic development on mortality: Comparative study of Kerala and West Bengal, Economic and Political Weekly (Bombay), 18(19/20/21): 877900.

Nag, Moni and Neeraj Kak. 1984. Demographic transition in a Punjab village, Population and Development Review 10(4): 661-678.

Notestein, Frank. 1953. Economic problems of population change, in Proceedings of the Eighth International Conference of Agricultural Economists (Oxford University Press). 
Pollak, Robert A. and Susan Cotts Watkins. 1993. Cultural and economic approaches to fertility: Proper marriage or mesalliance? Population and Development Review 19(3): 467-495.

Putnam, Robert. 1993. Making Democracy Work: civic traditions in modern Italy, Princeton, NJ: Princeton University Press.

Registrar-General of India, Vital Registration System 1981.

Registrar-General of India, Sample Registration System 1970-75, 1980-82, 1991-93.

Registrar-General of India. 1992. Primary Census Abstract of India, Paper 2 of 1992.

Ramasundaram, S.1995. Causes for the rapid fertility decline in Tamil Nadu: a policy planner's perspective, Demography India 24(1):13-22.

Satia, J.K. and Shireen Jejeebhoy (eds.) 1991. The Demographic Challenge: a study of four large Indian states, Bombay: Oxford University Press.

Skocpol, Theda.1994. France, Russia, China: a structural analysis of social revolutions, in T. Skocpol, Social Revolutions in the Modern World, Cambridge, UK: Cambridge University Press.

Visaria, Pravin.1995. Demographic transition and policy responses in India, Demography India 24(1):1-12.

Wade, Robert. 1982. Irrigation and Agricultural Politics in South Korea, Boulder, CO.:Westview Press.

Wade, Robert. 1985. The market for public office: why the Indian state is not better at development, World Development 13(4): 467-497.

Wade, Robert. 1997. How infrastructure agencies motivate staff: canal irrigation in India and the Republic of Korea, in A.Mody (ed.) Infrastructure Strategies in East Asia: the untold story, Washington D.C.: The World Bank, Economic Development Institute.

Weiss, Linda and John M.Hobson 1995. states and Economic Development: a comparative historical analysis, Cambridge, UK: Polity Press.

World Bank. 1997. World Development Indicators 1997. 
2
0
$\vdots$
0
0
0
0
0
0
0
0
0
0
0
0
$\vdots$
0
0
0
0

\section{Total Fertility Rate}
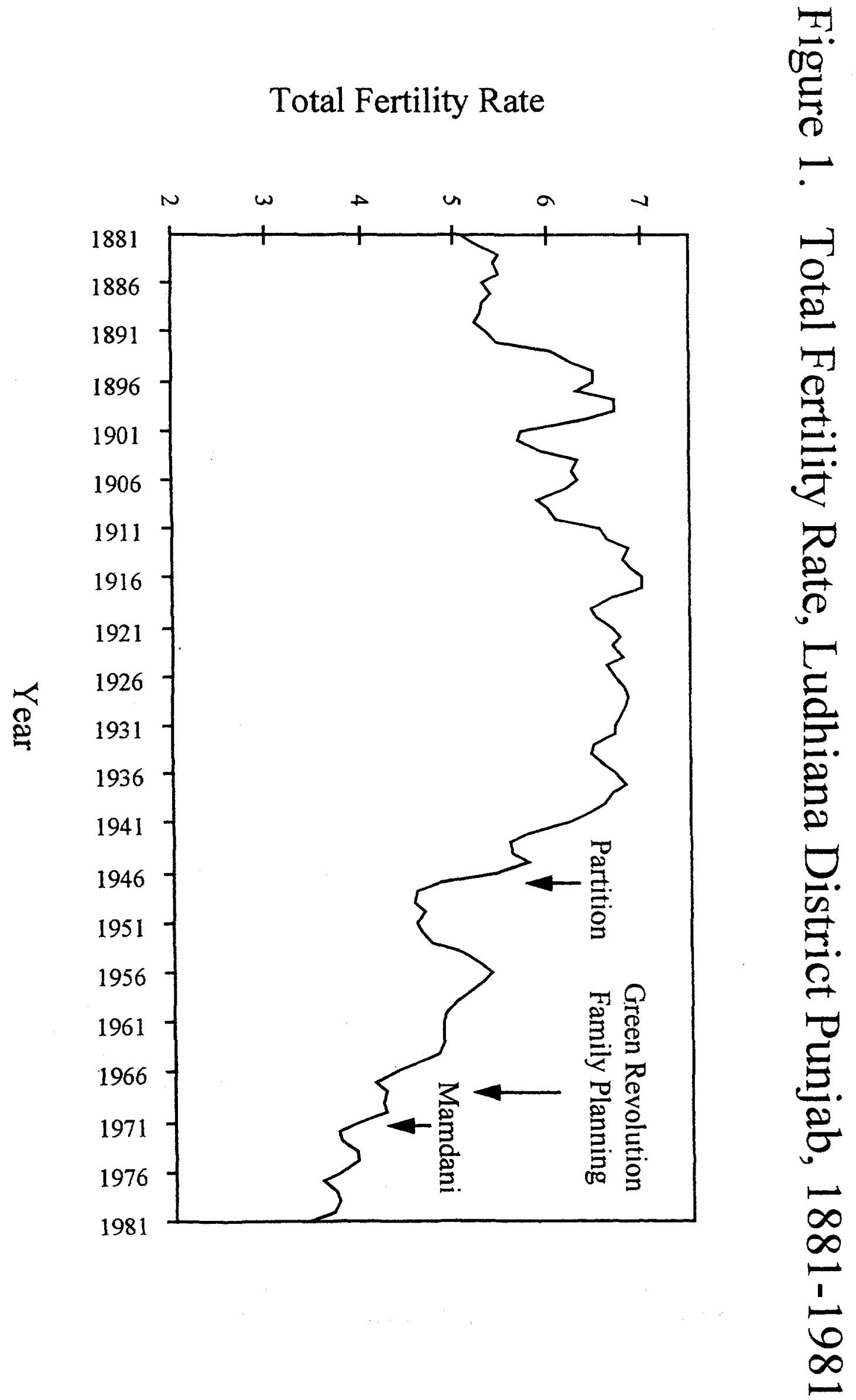
Figure 2

\section{Sweden, England, Brazil, S.Korea and India TFR}

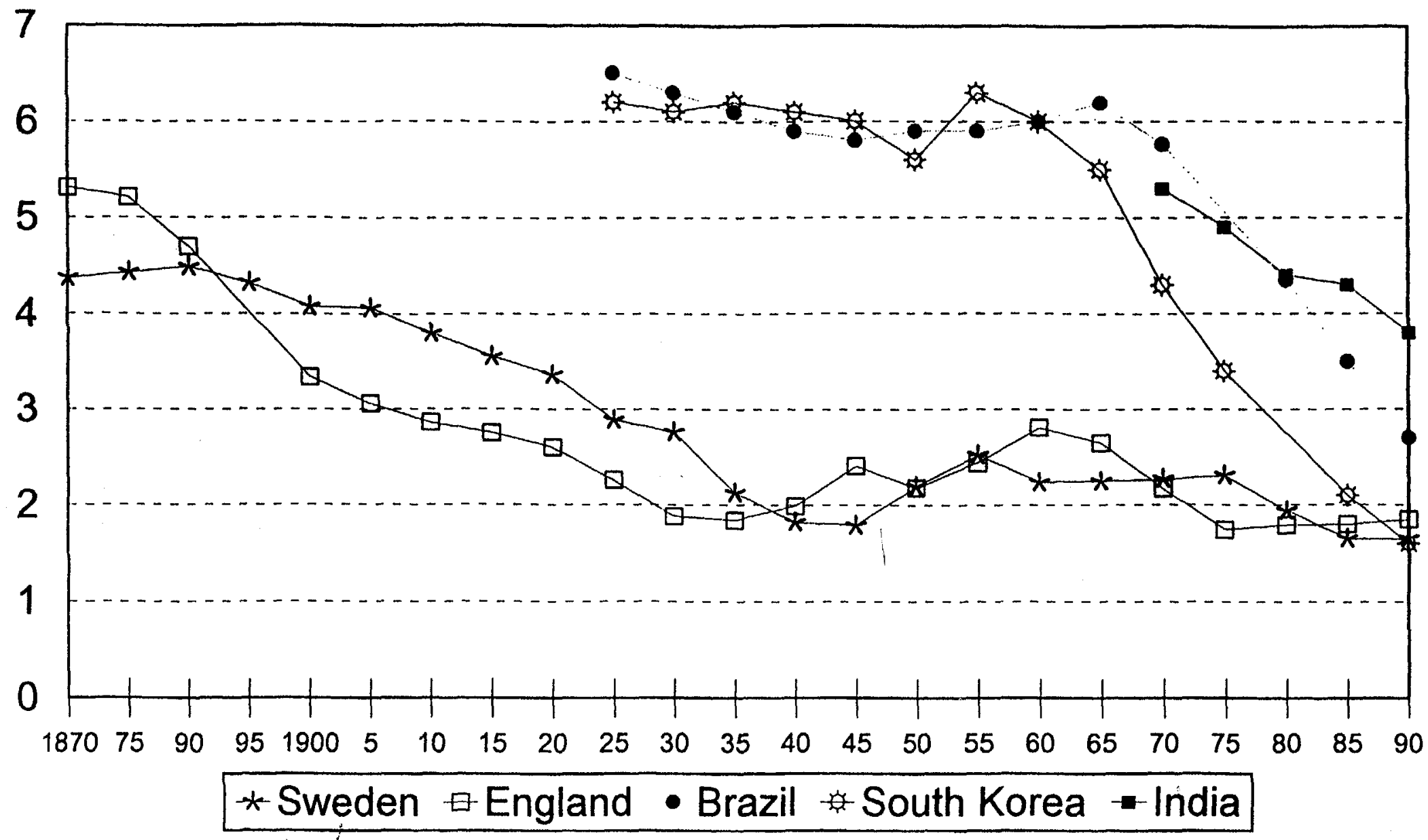

Source: Das Gupta, Martine and Chen (1997). 


\section{FIGURE 3}

\section{Schematic drawing of fertility decline in Asia}

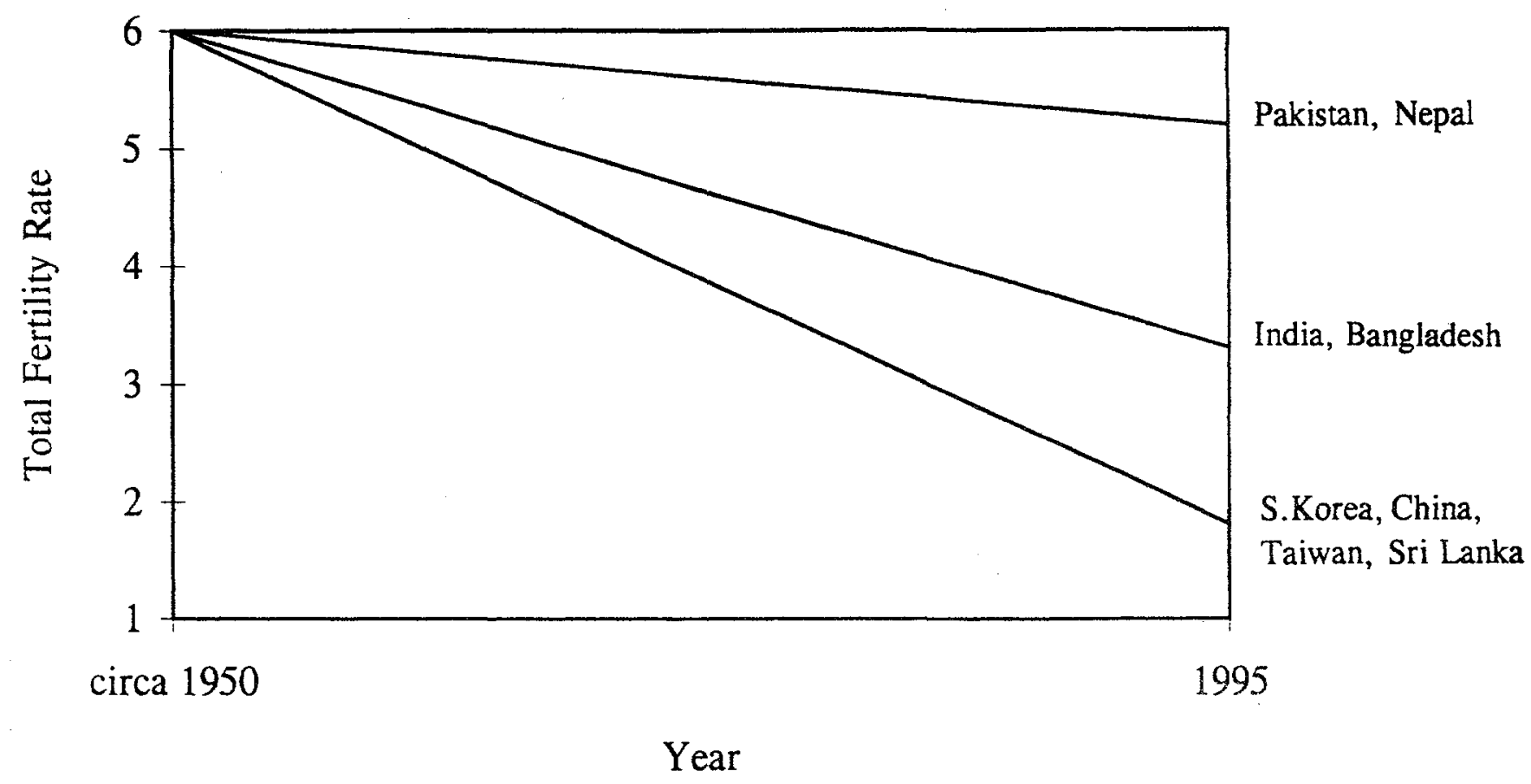


Table I. Indices of fertility and development, major States of India

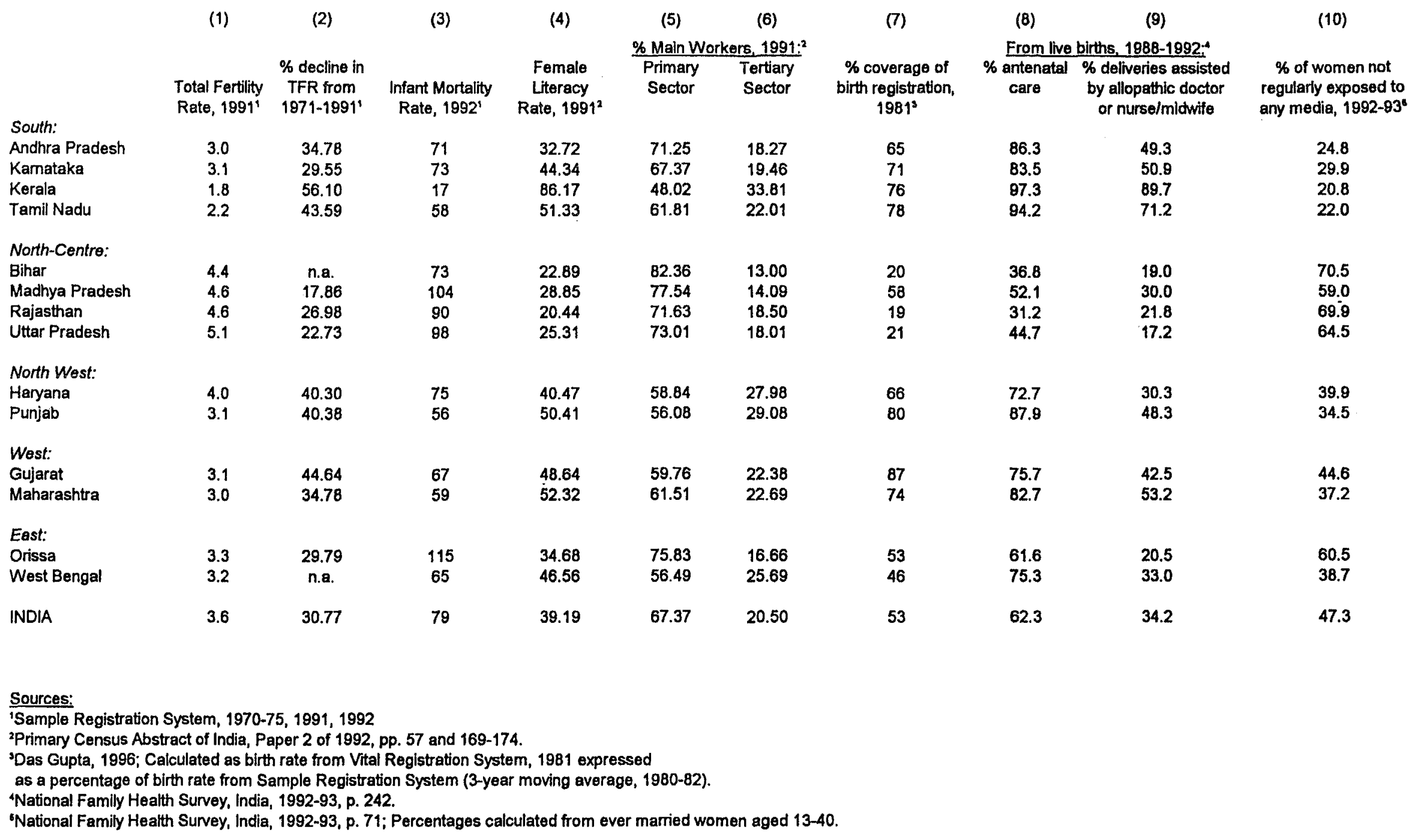




\begin{tabular}{|c|c|c|c|c|}
\hline & Title & Author & Date & $\begin{array}{l}\text { Contact } \\
\text { for paper }\end{array}$ \\
\hline WPS2110 & $\begin{array}{l}\text { Life during Growth: International } \\
\text { Evidence on Quality of Life and } \\
\text { Per Capita Income }\end{array}$ & William Easterly & May 1999 & $\begin{array}{l}\text { K. Labrie } \\
31001\end{array}$ \\
\hline WPS2111 & $\begin{array}{l}\text { Agricultural Land Reform in Postwar } \\
\text { Japan: Experiences and Issues }\end{array}$ & Toshihiko Kawagoe & May 1999 & $\begin{array}{l}\text { P. Kokila } \\
33716\end{array}$ \\
\hline WPS2112 & $\begin{array}{l}\text { Industrial Policy after the East Asian } \\
\text { Crisis: From "Outward Orientation" } \\
\text { To New Internal Capabilities? }\end{array}$ & Ashoka Mody & May 1999 & $\begin{array}{l}\text { S. Kpundeh } \\
39591\end{array}$ \\
\hline WPS2113 & $\begin{array}{l}\text { Wage Determination and Gender } \\
\text { Discrimination in a Transition } \\
\text { Economy: The Case of Romania }\end{array}$ & $\begin{array}{l}\text { Stefano Paternostro } \\
\text { David E. Sahn }\end{array}$ & May 1999 & $\begin{array}{l}\text { N. Nouviale } \\
34514\end{array}$ \\
\hline WPS2114 & $\begin{array}{l}\text { Economic Reforms and Total Factor } \\
\text { Productivity Growth in Latin America } \\
\text { And the Caribbean (1950-95): } \\
\text { An Empirical Note }\end{array}$ & $\begin{array}{l}\text { Pablo Fajnzylber } \\
\text { Daniel Lederman }\end{array}$ & May 1999 & $\begin{array}{l}\text { S. Holt } \\
37859\end{array}$ \\
\hline WPS2115 & $\begin{array}{l}\text { Foreign Investment and Productivity } \\
\text { Growth in Czech Enterprises }\end{array}$ & $\begin{array}{l}\text { Simeon Djankov } \\
\text { Bernard Hoekman }\end{array}$ & May 1999 & $\begin{array}{l}\text { R. Vo } \\
33722\end{array}$ \\
\hline WPS2116 & $\begin{array}{l}\text { Does Child Labor Displace } \\
\text { Schooling? Evidence on Behavioral } \\
\text { Responses to an Enrollment Subsidy }\end{array}$ & $\begin{array}{l}\text { Martin Ravallion } \\
\text { Quentin Wodon }\end{array}$ & May 1999 & $\begin{array}{l}\text { P. Sader } \\
33901\end{array}$ \\
\hline WPS2117 & $\begin{array}{l}\text { On the Size and Number of Regional } \\
\text { Integration Arrangements: A Political } \\
\text { Economy Model }\end{array}$ & Soamiely Andriamananjara & May 1999 & $\begin{array}{l}\text { L. Tabada } \\
36896\end{array}$ \\
\hline WPS2118 & $\begin{array}{l}\text { Developing Countries and the Next } \\
\text { Round of Multilateral Trade } \\
\text { Negotiations }\end{array}$ & Anne 0. Krueger & May 1999 & $\begin{array}{l}\text { L. Tabada } \\
36896\end{array}$ \\
\hline WPS2119 & $\begin{array}{l}\text { Tax Deductions, Environmental } \\
\text { Policy, and the "Double Dividend" } \\
\text { Hypothesis }\end{array}$ & $\begin{array}{l}\text { lan Parry } \\
\text { Antonio Bento }\end{array}$ & May 1999 & $\begin{array}{l}\text { R. Yazigi } \\
37176\end{array}$ \\
\hline WPS 2120 & $\begin{array}{l}\text { Can Africa Export Manufactures? } \\
\text { The Role of Endowment, Exchange } \\
\text { Rates, and Transactions Costs }\end{array}$ & Ibrahim A. Elbadawi & May 1999 & $\begin{array}{l}\text { C. Bernardo } \\
31148\end{array}$ \\
\hline WPS2121 & $\begin{array}{l}\text { Fiscal Management in Federal } \\
\text { Democracies: Argentina and Brazil }\end{array}$ & $\begin{array}{l}\text { William Dillinger } \\
\text { Steven B. Webb }\end{array}$ & May 1999 & $\begin{array}{l}\text { A. Lara } \\
88148\end{array}$ \\
\hline WPS2122 & $\begin{array}{l}\text { Decentralization and Fiscal } \\
\text { Management in Colombia }\end{array}$ & $\begin{array}{l}\text { William Dillinger } \\
\text { Steven B. Webb }\end{array}$ & May 1999 & $\begin{array}{l}\text { S. Webb } \\
38680\end{array}$ \\
\hline
\end{tabular}


Policy Research Working Paper Series

Title

WPS2123 Access to Land in Rural India

WPS2124 Social Exclusion and Land Administration in Orissa, India

WPS2125 Developing Country Agriculture and The New Trade Agenda
Author

Robin Mearns

Robin Mearns

Saurabh Sinha

Bernard Hoekman

$\mathrm{Kym}$ Anderson
Date

May 1999

May 1999

May 1999
Contact for paper

G. Burnett 82111

G. Burnett 82111

L. Tabada 36896

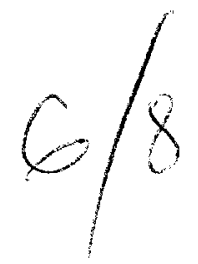

